\title{
Relevansi Nilai-Nilai Tarian "Raja Sine” dengan Pendidikan Nilai dalam Pembelajaran PKn Sekolah Dasar
}

\author{
Anna Kilu Muda ${ }^{1 *}$, Berty Sadipun ${ }^{2}$, Frumensius B. Dole ${ }^{3}$ \\ 1,2,3 Program Studi PGSD Universitas Flores Ende \\ Jalan Samratulangi, Kelurahan Pupire, Ende, Flores, Indonesia \\ ${ }^{*}$ Corresponding Author: Annakilumuda2607@gmail.com
}

\begin{abstract}
Info Artikel Abstract
Sejarah Artikel:

Diterima: $12 / 11 / 2019$

Direvisi: $11 / 12 / 2019$

Disetujui: 19/12/2019

Keywords: raja sine dance, values, $P K n$ learning

This stydy aims to determine the values in the Raja Sine dance that are relevant to the value education in civics learning in elementary schools. The type of cksplorratit qualitative research with the non-negative approach (culture) as atechnique for data collection is carried out by conducting in-depth interviews, documentation and participatory observation. The results showed that the values in the raja sine dance thar are relevant to the learning of civics are aesthetic values namely in class I KI 2 KD2.2, class II KI 2 KD2.2 and class III KI 2 KD2.2. the values of solidarity is in class II KI2 KD2.1. the value of togetherness (cooperation) is in class I KI 2 KD 2.3. the value of responsibility is in class I KI 2 KD2.1, class II KI IKD2.1. the valuesof discipline is in class I KI 2 KD2.2.2, class II KI 2 KD2.2 and class III KI 2 KD 2.2.
\end{abstract}

\begin{abstract}
Abstrak
Penelitian ini bertujuan untuk mengetahui nilai-nilai dalam tarian Raja Sine yang relevan dengan pendidikan nilai dalam pembelajaran PKn di sekolah dasar. Jenis penelitian kualitatif eksploratif dengan pendekatan etnografi (budaya) selanjutnya teknik pengumpulan data di lakukan dengan melakukan wawancara mendalam, dokumentasi dan observasi partisipatif. Hasil penelitian menunjukan bahwa nilai-nilai dalam tarian Raja Sine yang relevan dengan pembelajaran PKn adalah nilai estetika yaitu pada kelas I KI 2 KD2.2, kelas II KI 2 KD2.2 dan kelas III KI 2 KD2.2. Nilai solidaritas yaitu pada kelas II KI.2.KD2.1. Nilai kebersamaan (kerjasama) yaitu pada kelas I KI 2 KD2.3 dan Kelas III KI 2 KD2.3 Nilai tanggungjawab yaitu pada kelas I KI 2 KD2.1, kelas II KI 1 KD2.1. Nilai disiplin yaitu pada pada kelas I KI 2 KD2.2, kelas II KI 2 KD2.2 dan kelas III KI 2 KD2.2
\end{abstract}

\footnotetext{
"Alamat korespondensi:

Program Studi Pendidikan Guru Sekolah Dasar

Fakultas Keguruan dan Ilmu Pendidikan Universitas Flores

(C) 2020 Program Studi PGSD Universitas Flores

Kampus III Universitas Flores, Jln. Samratulangi,

Email: primagistrauniflor@gmail.com

Kelurahan Paupire, Ende, NTT

E-mail: Annakilumuda2607@ gmail.com
} 


\section{PENDAHULUAN}

Pendidikan adalah usaha sadar dan terencana untuk mewujudkan suasana belajar dan proses pembelajaran yang menyenangkan agar peserta didik secara aktif mengembangkan potensi dirinya untuk memiliki kekuatan spiritual keagamaan, pengendalian diri, kepribadian, kecerdasan, akhlak mulia serta keterampilan yang diperlukan dirinya masyarakat, bangsaa dan negara. (pasal 1 UU RI No 20 tahun 2003). Pendidikan juga dipahami sebagai suatu proses menanamkan dan mengembangkan apa yang dimiliki peserta didik seperti pengetahuan tentang hidup, sikap dalam hidup agar kelak ia dapat membedakan barang yang benar dan yang salah, yang baik dan yang buruk, sehingga kehadirannya ditengah-tengah masyarakat akan bermakna dan berfungsi secara optimal (Elmubarok 2009:3). Dari definisi tersebut dapat diketahui bahwa pendidikan adalah usaha atau proses yang ditujukan untuk membina kualitas sumber daya manusia seutuhnya agar ia dapat melakukan perannya dalam kehidupan secara fungsional dan optimal.

Nilai secara etimologi merupakan pandang kata value (bahasa inggris) (moral value). Dalam kehidupan sehari-hari nilai merupakan sesuatu yang berharga, bermutu, menunjukan kualitas dan berguna bagi manusia. Dalam pembahasan ini nilai merupakan kualitas yang berbasis moral. Dalam filsafat, istilah nilai digunakan untuk menunjukan kata benda abstrak yang artinya keberhargaan yang setara dengan berarti atau kebaikan (Zakiyah dan Rusdiana 2014:14).

Nilai adalah segala hal yang berhubungan dengan tingkah laku manusia mengenai baik atau buruk yang diukur oleh agama, tradisi, etika, moral dan kebudayaan yang berlaku dalam masyarakat. Pendidikan nilai adalah usaha sadar yang terencana dalam proses pembelajaran yang membentuk etika, moral dan budi pekerti peserta didik sebagai mahkluk Tuhan yang mempunyai keterampilan untuk diaplikasikan dalam kehidupan bermasyarakat, bangsa dan negara. Pendidikan nilai akan membuat anak didik tumbuh menjadi pribadi yang mengerti sopan, santun, memiliki cita rasa seni, sastra dan keindahan pada umumnya, mampu menghargai diri sendiri dan orang lain, bersikap hormat terhadap keluhuran martabat manusia, serta memiliki citra rasa moral dan rohani. Menurut Hasan (dalam Zakiyah dan Rusdiana 2014:62) pendidikan nilai adalah bentuk kegiatan pengembangan ekspresi nilai-nilai yang ada melalui proses sistematis dan kritis sehingga mereka dapat meningkatkan atau memperbaiki kualitas kognitif dan efektif dan afektif peserta didik.

Menurut Driyarkara (dalam Elmubarok 2009:44) tujuan pendidikan nilai meliputi tindakan mendidik yang berlangsung mulai dari usaha penyadaran nilai hingga perwujudan perilaku yang bernilai. Nilai yang dimiliki seseorang dapat mengekspresikan yang lebih disukai dan yang tidak disukai, dengan demikian dapat dikatakan bahwa nilai menyebabkan sikap. Nilai merupakan faktor penentu bagi pembentukan sikap, akan tetapi sikap seseorang ditentukan oleh jumlah nilai yang dimiliki seseorang. Sasaran pendidikan nilai adalah penanaman nilai-nilai luhur kepada diri peserta didik. Untuk mencapai tujuan dan sasaran secara efektif berbagai pendekatan, model dan metode dapat digunakan dalam proses pendidikan. Hal ini penting untuk memberikan variasi pada proses pendidikan sehingga menarik dan tidak membosankan peserta didik. Dalam proses pembelajaran pendidikan nilai dapat dikaitkan dengan kebudayaan yang ada di Indonesia kerena Indonesia dikenal dengan berbagai macam kebudayaan. Antara pendidikan dan kebudayaan terdapat hubungan yang sangat erat dalam arti keduanya berkenan dengan suatu hal yang sama ialah nilai- nilai.

Nilai-nilai merupakan inti dari setiap kebudayaan. Dalam hal ini khususnya nilainilai moral yang merupakan sarana pengatur dari kehidupan bersama, sangat menentukan didalam setiap kebudayaan. Lebih-lebih lagi didalam dunia yang terbuka ikatan nilai-nilai moral mulai melemah. Masyarakat mengalami krisis, krisis yang sangat parah dirasakan adalah krisis nilai-nilai moral.

Berdasarkan UU nomor 20 tahun 2003 penjelasan pasal 37 ayat 1 ditegaskan bahwa pendidikan kewarganegaran dimaksud untuk membentuk peserta didik menjadi manusia yang memiliki rasa kebangsaan dan cinta tanah air. Pendidikan kewarganegaraan juga merupakan mata pelajaran yang memiliki tujuan utama mengembangkan pengetahuan, sikap dan keterampilan sehingga siswa 
menjadi warga negara yang baik. Untuk mencapai tujuan tersebut seorang pendidik bisa menggunakan budaya/kebudayaan di tempatnya sebagai sumber pendidikan.

Raja sine merupakan tarian daerah atau tarian khas masyarakat Lewouran.Tarian ini menceritakan tentang semangat kerja sama,semangat solidaritas sebagai satu kesatuan ikatan sosial dalam sebuah gerakan menumbuk padi. Tuturan syair dari tarian tersebut menggambarkan para gadis Lewouran dari setiap suku,dipanggil dengan tanda bunyi lesung harus segera berkumpul. Nilai-nilai budaya dari tarian raja sine adalah salah satu pendidikan nilai yang perlu dipelihara dan dikembangkan. Maka dalam keadaan seperti ini perlu dikaji bagaimana menanamkan kembali nilai-nilai nasionalisme kepada peserta didik melalui pengintegrasian nilainilai budaya lokal dalam proses pembelajaran PKn.Hal ini dimaksud untuk memberikan pengertian dan pemahaman tentang nilai-nilai budaya lokal dari daerah setempat yang perlu dipertahankan dan dikembangkan.

\section{METODE PENELITIAN}

Jenis Penelitian Jenis penelitian dalam penelitian ini ialah menggunakan penelitian kualitatif. Pendekatan kualitatif merupakan pendekatan penelitian yang memerlukan pemahaman yang mendalam dan menyeluruh berhubungan dengan objek yang diteliti bagi menjawab permasalahan untuk mendapat datadata kemudian dianalisis dan mendapat kesimpulan penelitian dalam situasi dan kondisi yang tertentu. Menurut Sudjarwo(dalam Iskandar 2013:205) pendekatan penelitian kualitatif harus memiliki prinsip yaitu peneliti harus menjadi partisipan yang aktif bersama objek yang diteliti, disini diharapkan peneliti mampu melihat fenomena dilapangan secara struktural dan fungsional.

Penelitian ini menggunakan pendekatan etnografi (budaya). Penelitian etnografi merupakan metode penelitian yang banyak dilakukan dalam bidang antropologi terutama yang berhubungan dengan setting budaya. Penelitian ini bertujuan untuk mendeskripsikan tentang budaya masyarakat primitif dalam bentuk cara berpikir, cara hidup, berperilaku, bersosial. Penggunaan pendekatan ini dimaksudkan agar penyimpulan data tentang nilai-nilai yang terkandung dalam tarian Raja Sine dipahami sesuai perspektif pelaku budaya tersebut.

Penelitian akan dilaksanakan pada bulan April sampai Mei 2019 bertempat di Lewouran, Desa Birawan, Kecamatan Ilebura, Kabupaten Flores Timur. Subjek penelitian ini adalah masyarakat Lewouran sebagai pelaku/pemilik tarian Raja Sine.

Prosedur penelitian adalah dengan menggunakan jenis penelitian kualitatifyang dilakukan dengan teknik wawancara mendalam dan dokumentasi untuk meneliti nilai-nilai budaya dari tarian Raja Sine yang dapat diterapkan dalam pembelajaran PKn

Wawancara yang dilakukan dalam penelitian ini dilakukan secara mendalam dimaksud untuk memperoleh gambaran yang jelas tentang apa yang dikemukakan, dipikirkan, dirasakan dan apa saja yang diketahui oleh pihak yang diwawancarai.Wawancara mendalam merupakan bentuk komunikasi antara peneliti dengan subjek yang diteliti dengan mengajukanpertanyaan-pertanyaan dalam mencari informasi berdasarkan tujuan.Wawancara dapat dilakukan secara formal dan informal (terjadwal dan tidak terjadwal) ditempat resmi dan ditempat umum atau tidak resmi.Data yang ingin didapat dari wawancara ini adalah nilai-nilai budaya apa saja yang dapat diterapkan dalam pembelajaran PKn dengan menggunakan tarian Raja Sine.

Dokumentasi merupakan catatan peristiwa yang sudah berlalu yang berbentuktulisan gambar atau karya monumental seseorang (Sugiyono,2009:240) peneliti terhadap dokumentasi dilakukan dengan mendapatkan data yang berhubungan dengan nilai-nilai budaya yang ada ditempat penelitian.

Observasi yang dilakukan dalam penelitian ini menggunakan teknik observasi pertisipasif dimana peneliti berinteraksi secara penuh dalam situasi sosial dengan subjek penelitian.Teknik ini digunakan untuk mengamati, memahami peristiwa secara cermat, mendalam dan terfokus terhadap 
subjek penelitian, baik dalam suasana formal maupun santai.

Analisis data penelitian ini dibuat dengan menggunakan model analisis interaktif yang dikembangkan oleh Milles dan Huberman sebagaimana dalam bagan berikut:

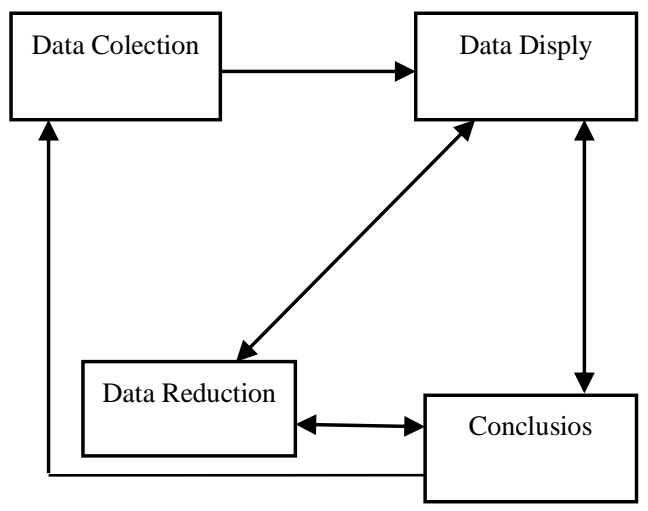

Gambar 1.Model Analisis Interaktif (Comporent of Data Analysis) (Milles dan Huberman dalam Iskandar 2013:224)

Pengecekan keabsahan data demi kredibilitas penelitian dan objektifitas data dilakukan dengan teknik:triangulasi, diskusi dengan teman sejawat, dan mengumpulkan data tambahan jika diperlukan.

Penelitian dilakukan dengan mengikuti tahapan-tahapan pengumpulan informasi/data awal, penyusunan desain penelitian, pelaksanaan kegiatan penelitian diakhiri dengan pengelolahan dan analisis data

\section{HASIL DAN PEMBAHASAN}

\section{A. Hasil Penelitian}

\section{Sejarah Singkat Tarian Raja Sine}

Tarian Raja Sine adalah tarian khas masyarakat Lewouran yang sudah ada sejak dulu. Asal mula munculnya tarian ini belum diketahui secara pasti. Namun tarian ini sudah ada sejak dahulu kala dan biasanya dilakukan oleh masyarakat Lewouran pada saat ada ritual adat perkawinan maupun acara adat lainya. Berdasarkan hasil wawancara dengan Mama Nika Kwure selaku tokoh masyarakat di Dusun Lewouran Desa Birawan bahwa:

"Raja sine ini sudah ada sejak zaman dahulu. Raja Sine dikenal karena pada saat menumbuk padi, syair yang dinyanyikan oleh gadis-gadis tersebut dengan sendirinya dinyanyikan dan mengikuti irama bunyi lesung dan alu yang berbunyi. Dimana dapat diartikan bahwa Raja Sine adalah Tarian menumbuk padi yang dilakukan oleh gadis-gadis Lewouran. (wawancara dilakukan pada hari Senin,29 April 2019).

Ungkapan dari Mama Nika diatas mengenai tarian Raja Sine diperkuat lagi oleh narasumber kedua yaitu oleh Bapak Longginus Nuli Muda. Beliau mengatakan bahwa:

"Raja Sine merupakan tarian menumbuk padi sedangkan syair yang dinyanyikan dalam tarian Raja Sine yaitu ratapan atau pujian terhadap tehe(padi) sebagai sumber makanan. Ketika dalam menumbuk padi selalu ada ratapan bagaimana masyarakat dulu menghormati makanan dan kegembiraan mereka menghasilkan beras dari padi tersebut. (wawancara dilakukan pada hari selasa, 30 april 2019)

Tarian Raja Sine adalah tarian yang sudah ada sejak dulu dan tarian yang menceritakan bagaimana proses menumbuk Padi. Hal yang sama juga diungkapkan oleh narasumber ketiga yaitu Bapak Metias Wato Kwuta.Beliau mengatakan bahwa:

Tarian Raja Sine adalah tarian tradisi kemomu kebare (pemuda pemudi) yang hidup pada zaman dahulu atau kumpulan gadis-gadis lewouran yang bersama-sama menumbuk padi. Pada zaman dahulu masyarakat Lewouran hidup berpisahpisah sesuai sukunya masing-masing dan tinggal di Rie-rie atau due didalam hutan. Karena sudah ada pennyumpahan adat untuk berkumpul dan hidup bersama maka terkumpulah pula gadis-gadis dan pemuda-pemuda Lewouran.. (wawancara dilakukan pada hari Selasa, 30 April 2019)

Hampir sama dengan pendapat ketiga narasumber di atas, ibu Lusia Ema Kwuta Menambahkan :

"Raja Sine merupakan sebuah tarian menumbuk padi dengan menggunakan alu dan lesung serta nyiru untuk memisahkan beras dari padi yang sudah ditumbuk tadi. Pada zaman dahulu tarian Raja Sine ini dilakukan pada saat mau ada ritual adat seperti perkawinan, pembuatan rumah atau membuka lahan baru. Karena membutuhkan beras yang banyak masyarakat lewouran dari setiap suku datang dan saling membantu dengan sukarela tanpa membedakaan suku yang 
dianutnya. Hanya dengan tanda bunyi lesung dan teriakan kata jug jo esemua gadis dari setiap suku datang berkumpul menumbuk padi, karena banyak orang yang sudah datang dan ramai setiap syair pujian terhadap kampung halaman dan padi dinyanyikan oleh gadis-gadis tersebut sesuai dengan bunyi lesung dan alu sambil menari mengikuti irama lesung dan alu tadi. Karena semakin ramai pemudapemuda juga tertarik dan datang membantu gadis-gadis tersebut. (wawancara dilakukan pada haris Kamis, 2 Mei 2019).

\section{Perlengkapan yang digunakan dalam Menari}

\section{a. Pengiring dalam Tarian Raja Sine}

Penggiring yang dimaksud disini merupakan alat musik yang digunakan pada saat tarian Raja Sine dilaksanakan. Alat musik disini sangatlah berperan penting dalam meramaikan sebuah tarian. Bukan hanya menikmati tarian saja tetapi harus sesuai dengan alat musik yang digunakan, sehingga perpaduan antara alat musik dengan gerakan menjadi indah dipandang dan menarik.

Berdasarkan hasil wawancara yang diperoleh peneliti, dari beberapa narasumber mengenai alat musik bahwa alat musik yang digunakan tidak menggunakan alat musik khusus tetapi tarian ini diiringi dengan suara tumbukan Alu dan lesung.

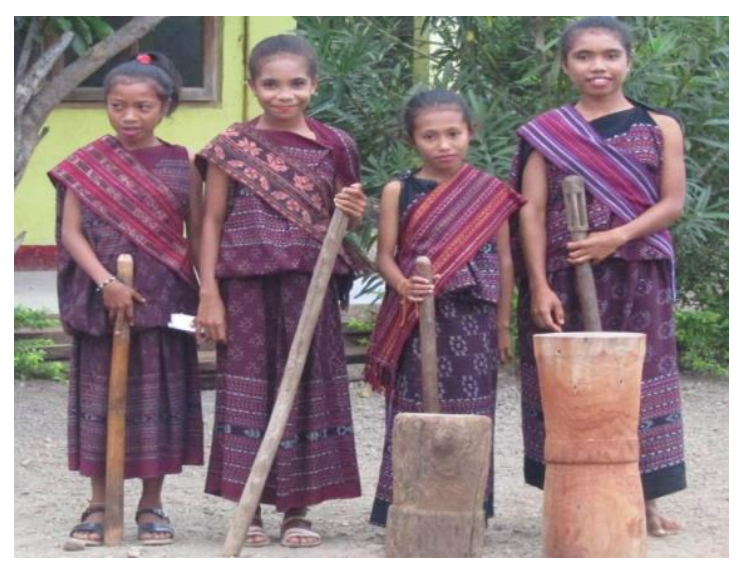

Gambar 1: Alu dan Lesung sebagai Alat Musik Pengiring Tarian Raja Sine (Sumber: Dokumen Ana Kilu Muda)

Berikut hasil wawancara dari mama Nika Kwure pada hari senin 29 April 2019 mengatakan bahwa:
"Mereka hanya menari mengikuti irama bunyi alu dan lesung.Syair yang dinyanyikan juga mengikuti irama bunyi alu dan lesung tersebut."

Ungkapan dari Mama Nika diatas mengenai alat musik dalam tarian Raja Sine diperkuat lagi oleh narasumber kedua yaitu oleh Bapak Longginus Nuli Muda pada hari selasa 30 April 2019.Beliau mengatakan bahwa:

"Alat-alat yang digunakan dalam tarian ini adalah nuhu,alo, lida dan baku. Para penari menari mengikuti bunyi suara alu dan lesung dan syair yang dinyanyikan juga harus mengikuti irama lesung dan alu tadi.

Hal yang sama pula diungkapkan oleh narasumber ketiga yaitu Bapak Metias Wato Kwuta pada hari selasa 30 April 2019. Beliau mengatakan bahwa:

"Nuhu, alo retu, baku dan lida. (lesung, alu yang berbunyi, bakul dan nyiru) karena pada saat menumbuk padi bunyi alu dan lesung breko (enak didengar) maka berkumpul pula pemudapemuda untuk membantu dan membuat suasana tambah ramai. Pada saat itu padi dianggap sebagai raja makanan yang harus dihormati.

Hampir sama dengan pendapat Bapak Metias Wato Kwuta, Ibu Lusia Ema Kwuta menambahkan :

"dalam tarian ini tidak ada alat musik seperti gendang gong.Tapi kita menggunakan Alu dan Lesung. Para penari menari mengikuti irama suara tumbukan Alu dan lesung. Dimana Alu dan lesung adalah alat yang digunakan untuk menumbuk padi" (wawancara dilakukan pada tanggal 2 Mei 2019).

\section{b. Pakaian dalam menari}

Pakaian merupakan kostum yang digunakan seseorang pada saat menari. Pakaian juga merupakan salah satu perlengkapan khas Flores Timur yang biasa digunakan/dipakai pada saat acara adat. Dalam menari harus kelihatan cantik, elok, menawan dan bisa menarik perhatian penonton. Busana yang digunakan oleh penari dari setiap daerah juga berbedabeda.

Berdasarkan hasil wawancara yang diperoleh peneliti, dari beberapa narasumber mengenai busana yang digunakan yaitu mengunakan sarung, selempang tenun Khas masyarakat Lewouran sendiri. Berikut hasil 
wawancara dari Mama Nika Kwure pada hari Senin 29 April 2019 mengatakan bahwa:

"Busana yang digunakan yaitu kwate ua sugi sarung khas masyarakat Lewouran yang digunakan oleh gadis-gadis dan selendang serta snae yang digunakan oleh pemuda-pemuda".

Ungkapan dari Mama Nika diatas mengenai busana yang digunakan dalam tarian Raja Sine diperkuat lagi oleh narasumber kedua yaitu oleh Bapak Longginus Nuli Muda pada hari Selasa 30 April 2019. Beliau mengatakan bahwa:

"Busana yang digunakan penari perempuan adalah tenun khas masyarakat lewouran yaitu kwate, selempang dan selendang sedangkan penari laki-laki menggunakan snae, baju berwarna putih dan selempang yang diikat dikepala dan dipegang.

Syair yang dinyanyikan dalam tarian Raja Sine menceritakan bagaimana kehidupan masyarakat pada zaman dahulu

Narasumber ketiga Metias Wato Kwuta mengungkapkan hal yang sama mengenai Busana yang digunakan bahwa:

"Busana yang digunakan pada saat menumbuk padi yaitu gadis-gadis menggunakan kwate dengan ua sugi (tenun khas masyarakat Lewouran) sedangkan laki-laki menggunakan snae." (Wawancara pada tanggal 30 April 2019)

Hampir sama dengan pendapat ketiga narasumber di atas mengenai busana yang digunakan, ibu Lusia Ema Kwuta menambahkan bahwa:

"Dalam melakukan tarian raja sine gadis-gadis juga menggunakan selendang untuk menari. Busana yang digunakan oleh penari perempuan dalam melakukan tarian Raja Sine yaitu kwate ua sugi(hasil tenun khas masyarakat Lewouran dan yang dipakai dengan cara ikat dipinggang dengan menggunakan tali dan semat di kedua bahu menggunakan peniti) dan snae dipakai oleh lakilaki serta selempang yang diikat di kepalanya dan dipegang".(wawancara pada tanggal 2 Mei 2019)

\section{Proses Pelaksanaan Tarian Raja Sine}

Menurut mama Nika Kwure segala sesuatu yang perlu dipersipkan sebelum melakukan tarian Raja Sine yaitu: pada saat melakukan tarian Raja Sine alat yang perlu dipersiapkan alu,lesung,bakul dan busana yang digunakan yaitu kwate ua sugi sarung khas masyarakat Lewouran yang digunakan oleh gadis-gadis dan selendang serta snae yang digunakan oleh pemuda-pemuda (wawancara dilakukan pada tanggal 29 April 2019).

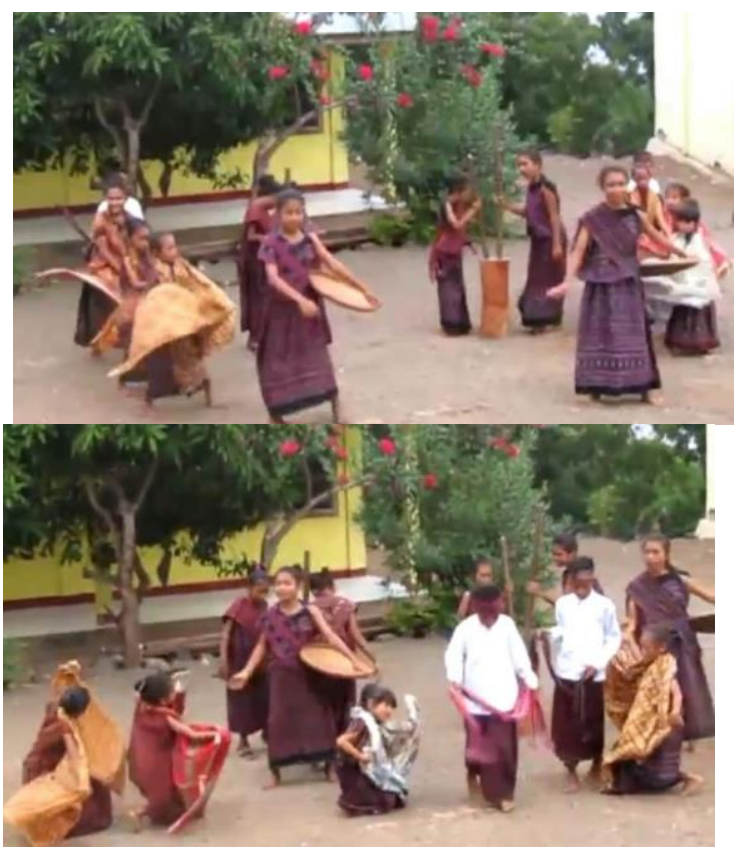

Gambar 2: Anak-anak SDK Lewowuran Flores Timur NTT sedang menarikan Tarian Raja Sine (Sumber: Dokumen Ana Kilu Muda

Ungkapan dari Mama Nika di atas mengenai segala sesuatu yang harus dipersiapkan sebelum melakukan tarian Raja Sine diperkuat lagi oleh narasumber kedua yaitu Ibu Lusia Ema Kwuta.Beliau mengatakan bahwa:

"Pada saat sekarang sebelum melakukan tarian Raja Sine ini banyak Hal yang Harus dipersipakan karena seiring perkembangan zaman alat-alat yang digunakan untuk menumbuk padi tadi sudah tidak terawat lagi terutama Lesung dan Alu Retu (Alu yang jika digunakan dapat menghasilkan bunyi). Hal lain yang perlu dipersiapkan yaitu nyiru dan busana. Busana yang digunakan harus benar-benar motif asli hasil tenun masyarakat Lewouran." (wawancara dilakukan pada tanggal 2 Mei 2019 )

Dalam pelaksanaan tarian Raja Sine ini yang perlu diperhatikan yaitu alat dan busana yang digunakan. Sedangkan proses pelaksaan tarian bisa dilakukan kapan saja dan dibawakan oleh semua kalangan.

Berdasarkan hasil wawancara yang telah dilakukan peneliti kepada narasumber kedua yaitu bapak Longginus Nuli Muda pada hari 
selasa tanggal 30 April 2019. Beliau mengatakan bahwa:

"Tarian ini biasa dipentaskan kapan saja seperti
pada saat ada acara-acara besar dimasyarakat
seperti penerimaan tamu sebagai hiburan yang
menunjukan bagaimana kebersamaan masyarakat
Lewouran"

Ungkapan dari beliau di atas diperkuat lagi oleh Narasumber ketiga yaitu oleh Bapak Metias Wato Kwura pada hari selasa tanggal 30 April 2019. Beliau mengatakan bahwa:

"Tarian ini bisa dibawahkan kapan saja. Jumlah orang yang mengikuti tarian Raja Sine ini tergantung kesepakatan sendiri dan sebelum melakukan tarian Raja Sine tidak melalui proses adat"

Narasumber keempat yaitu Lusia Ema Kwuta menambahkan Lagi mengenai proses pelaksaan dan jumlah penari yang membawahkan tarian Raja Sine. Beliau mengatakan bahwa:

"Jumlah orang yang membawakan tarian raja sine yaitu 10-20 orang.Tarian ini bisa dilakukan kapan saja dan dibawakan oleh semua kalangan"

\section{Nilai-Nilai Budaya dalam Tarian Raja} Sine

Setiap daerah tentunya mempunyai kebudayaannya masing masing. Kebudayaan ini menjadi ciri khas masyarakat yang ada pada daerah tersebut yang harus dijaga dan dipertahankan. Tarian Raja Sine adalah tarian khas masyarakat Lewouran yang sudah ada sejak dahulu.

Berdasarkan hasil wawancara yang diperoleh peneliti, dari beberapa narasumber mengenai nilai budaya dalam tarian Raja Sine. Berikut hasil wawancara dari mama Nika Kwure pada hari senin 29 April 2019 mengatakan bahwa:

"Masyarakat pada saman dahulu hidup berpisahpisah dan tinggal dibukit-bukit. Meskipun tinggal berpisah-pisah masyarakat tetap saling membantu jika salah satu suku melaksaanakan acara adat semua suku lain datang berkumpul dan saling membantu. Karena pada saman dahulu masyarakat belum mengenal alat giling padi maka alu dan lesung adalah alat utama yang digunakan untuk menghasilkan beras.Jadi kita sekarang juga harus seperti nenek moyang kita ini, tidak boleh masa bodoh jika melihat orang lain membutuhkan bantuan kita dan untuk generasi sekarang harus mempertahankan budaya adat ini".

Ungkapan dari Mama Nika diatas mengenai nilai budaya diperkuat lagi oleh narasumber kedua yaitu oleh Bapak Longginus Nuli Muda. Beliau mengatakan bahwa:

Raja sine adalah tarian yang sudah ada sejak zaman nenek moyang yang harus kita jaga dan kembangkan untuk generasi berikutnya.Dengan adanya tarian tersebut masyarakat Lewouran yang pada zaman dulu yang hidup berpisah-pisah sesuai suku mereka masing-masing dapat berkumpul dan saling membantu. Dengan adanya tarian ini semangat persaudaraan dan persatuan semakin erat sehingga tarian ini dijaga dan menjadi tarian khas/daerah masyarakat Lewouran. Tarian ini dibawahkan oleh semua suku yang ada di Lewouran dan dipentaskan kapan sajaseperti pada saat ada acara-acara besar dimasyarakat seperti penerimaan tamu sebagai hiburan yang menunjukan bagaimana kehidupan dan kebersamaan masyarakat Lewouran. (wawancara pada hari selasa,tanggal 30 April 2019)

Ungkapan dari beliau di atas diperkuat lagi oleh narasumber ketiga yaitu oleh Bapak Metias Wato Kwura pada hari selasa tanggal 30 April 2019. Beliau mengatakan bahwa:

Dalam tarian ini ada 3 gerakan penting yang dilakukan. Gerakan yang mempragakan bagaimana cara menumbuk padi yaitu gerak bajo tehe, gerak sepi tehe dan gerak soka sele.Jadi dilihat dari gerakan ini kita bisa mengetahai bagaimana tanggung jawab mereka dalam membawahkan tarian ini, Kerja sama yaitu dimana semua gadis-gadis Lewouran yang saling membantu tanpa paksaan. Walaupun hidup terpisah-pisah jika ada hajatan dalam suatu suku semua gadis atau pemuda-pemuda dari suku lain datang membantu".

Narasumber keempat yaitu Lusia Ema Kwuta menambahkan Lagi mengenai nilai budaya dalam tarian Raja Sine. Beliau mengatakan bahwa: "Nilai yang terkandung dalam tarian Raja Sine yaitu pertama nilai keindahan yaitu Busana yang digunakan oleh penari perempuan yaitu kwate ua sugi (sarung tenun khas masyarakat lewouran), selempang dan selendang sedangkan penari laki-laki menggunakan snae, baju berwarna putih dan selempang yang diikat dikepala dan dipegang. Alat musik yang digunakan yaitu Alu dan 
Lesung alat perlengkapan lain yang digunakan yaitu bakul dan nyiru. Dalam tarian ini juga ada 3 gerakan penting yaitu gerakan bajo tehe, gerakan sepi tehe dan gerakan soka sele yang dilakukan sesuai irama Alu dan lesung.

Nilai yang lainnya yaitu nilai kerjasama dimana Masyarakat dulu itu biar hidup terpisah tapi tetap saling membantu. Mereka hanya mendengar suara lesung dan Alu dan teriakan jug jo $e$ mereka dengan sendirinya datang berkumpul dan membantu sesama mereka yang menumbuk padi. Hal ini juga harus ditiru oleh kita sekarang. Ada juga jika dilihat dari keindahan busana yang digunakan menegaskan bahwa generasi sekarang tidak boleh menggunakan motif lain dalam membawahkan tarian ini, jadi generasi sekarang juga harus belajar menenun. Nilai budaya lain yang bisa diambil jika dilihat dari gerakan dalam tarian Raja Sine yaitu bagaimana semangat kerjasama nenek moyang kita serta tanggung jawab penari dalam memperagakan bagaimana menghasilkan beras.

\section{B. Pembahasan}

\section{Nilai-nilai yang terkandung Tarian Raja Sine \\ a. Nilai Keindahan atau Estetika}

Tarian adat mengacu pada nilai keindahan (estetika) yang berasal dari ekspresi dan hasrat manusia akan cita rasa keindahan yang dinikmati dengan mata dan telinga. Sebagai manusia yang memiliki cita rasa tinggi, manusia menghasilkan berbagai corak kesenian diri yang sederhana hinggah yang kompleks. Kesenian tradisional adalah sebagai warisan secara turun temurun merupakan bentuk kesenian yang sudah menyatu dengan masyarakat, sangat berkaitan dengan adat istiadat dan berhubungan erat dengan nilainilai kedaerahan.

Estetika menelaah dan membahas tentang seni dan keindahan serta tanggapan manusia terhadapnya. Estetika juga dimaknai sebagai kepekaan terhadap seni dan keindahan. Manusia berbudaya adalah manusia yang pikiran dan akalnya sudah maju. Dengan demikian, estetika manusia berbudaya yang dimaksud disini berkaitan dengan penerapan manusia berbudaya terhadap seni dan keindahan (Jurahman 2014).Demikian pula dengan tarian Raja Sine terdapat unsur seni dalam gerakan-gerakan yang dimainkan oleh penari dan busana adat yang digunakan oleh penari.

Hasil wawancara dengan Ibu Lusia Ema Kwuta pada tanggal 2 mei 2019 mengatakan bahwa Busana yang digunakan oleh penari perempuan yaitu kwate ua sugi (sarung tenun khas masyarakat lewouran), selempang dan selendang sedangkan penari laki-laki menggunakan snae, baju berwarna putih dan selempang yang diikat dikepala dan dipegang. Alat musik yang digunakan yaitu Alu dan Lesung alat perlengkapan lain yang digunakan yaitu bakul dan nyiru. Dalam tarian ini juga ada 3 gerakan penting yaitu gerakan bajo tehe, gerakan sepi tehe dan gerakan soka sele yang dilakukan sesuai irama Alu dan lesung. Pakaian yang digunakan benar-benar hasil tenun masyarakat Lewouran yang dengan motifnya sendiri.Cara menggunakannya juga berbeda khususnya penari perempuan yang dikenal dengan istilah ikat dipinggang semat di bahu. Serta gerakan kaki dan tangan penari kompak dan sesuai dengan bunyi ketukan alu dan lesung (catatan lapangan)

Dari hasil wawancara diatas menunjukkan bahwa ragam gerak yang dilakukan oleh penari menggambarkan bagaimana proses menghasilkan beras yang dilakukan oleh nenek moyang pada zaman dahulu serta busana tarian adat yang menambah nilai seni yang menunjukan bagaimana ciri khas masyarakat Lewouran.

\section{b. Nilai Solidaritas}

Manusia pada hakikatnya adalah mahkluk sosial yang sangat membutuhkan orang lain disekitarnya. Multikulturalisme yang ada di Indonesia mempunyai banyak keragaman dan kekayaan yang sangat membutuhkan solidaritas antar sesama umat manusia demi tercapainya kehidupan yang harmonis. Mengacu pada negara Indonesia yang mempunyai budaya beraneka ragam agama yang diakui dan suku yang bermacam-macam.

Perasaan solidaritas, senasip, seperjuangan, setia dan memiliki sifat dan rasa yang solider merupakan bagian yang penting dalam kehidupan manusia, karena manusia hidup membutuhkan orang lain. Rasa solidaritas benar-benar terasa ketika adanya keterlibatan subjek yang lain untuk saling membantu. Hal 
inilah yang terlihat dalam upacara tarian Raja Sine keterlibatan semua pihak pada masyarakat Lewouranterlihat jelas bahwa perasaan solidaritas antara sesama warga masyarakat sangat tinggi. Seperti yang dijelaskan oleh mama Nika Kwure (wawancara pada tanggal 29 April 2019) mengatakan bahwa: Masyarakat pada zaman dahulu hidup berpisah-pisah dan tinggal dibukit-bukit. Meskipun tinggal berpisah-pisah masyarakat tetap saling membantu jika salah satu suku melaksaanakan acara adat semua suku lain datang berkumpul dan saling membantu. Jadi kita sekarang juga harus seperti nenek moyang kita ini.Kita tidak boleh masa bodoh jika melihat orang lain membutuhkan bantuan kita.

Dari hasil wawancara di atas menjelaskan bahwa hubungan antara manusia yang satu dengan manusia yang lain sangat dibutuhkan guna untuk melengkapi kekurangan di antara manusia dalam bermasyarakat. Pada saat pementasan tarian ini semua masyarakat ikut ambil bagian dan turut merasaakan kebahagiaan.

\section{c. Nilai kebersamaan (Kerja Sama)}

Pada prinsipnya upacara tarian Raja Sine merupakan suatu bentuk upacara untuk membangun kebersamaan, persatuan dan kesatuan dalam pergaulan hidup masyarakat Lewouran. Dalam upacara ini nilai kerjasama terwujud dalam kekompakan antara semua suku yang di dusun Lewouran. Makna kebersamaan menggambarkan hubungan manusia sebagai mahkluk sosial, tidak dapat hidup sendiri tapi saling bergantung satu sama yang lain. Fungsi dan peran integrasi khususnya peranan tokoh adat dan masyarakat sangat penting dalam menjaga keutuhan hubungan antara masing-masing anggota masyarakat pada suatu daerah dalam menjaga rasa persaudaraan agar tetap erat.

Makna kebersamaan yang dimaksud disini adalah terciptanya sikap dan perilaku saling memperkuat antara satu dengan yang lainnya, rasa kebersamaan, persatuan, terciptanya kerukunan hidup dalam masyarakat Lewouran saling tolong menolong,gotong royong, untuk meringankan beban yang di alami salah satu masyarakatnya. Masyarakat Lewouran mengganggap tarian Raja Sine adalah sebuah tarian yang mempersatukan masyarakatnya melalui kebersamaan mereka dalam menumbuk padi. Seperti yang dijelaskan oleh bapak Longginus Nuli Muda pada tanggal 30 April 2019. Beliau menjelaskan bahwa: Dengan adanya tarian tersebut masyarakat Lewouran yang pada zaman dulu yang hidup berpisah-pisah sesuai suku mereka masingmasing dapat berkumpul dan saling membantu. Dengan adanya tarian ini semangat persaudaraan dan persatuan semakin erat sehingga tarian ini dijaga dan menjadi tarian khas/daerah masyarakat Lewouran.

Hal yang sama juga dijelaskan oleh Bapak Metias Wato Kwuta pada tanggal 30 Mei 2019 menjelaskan: Dalam tarian ini ada 3 gerakan penting yang dilakukan. Gerakan yang memperagakan bagaimana cara menumbuk padi yaitu gerak bajo tehe, gerak sepi tehe dan gerak soka sele.Jadi dilihat dari gerakan ini kita bisa mengetahai bagaimana tanggungjawab mereka dalam membawakan tarian ini, kerja sama yaitu dimana semua gadis-gadis Lewouran yang saling membantu tanpa paksaan. Walaupun hidup terpisah-pisah jika ada hajatan dalam suatu suku semua gadis atau pemuda-pemuda dari suku lain datang membantu.

Hasil wawancara diatas menjelaskan bahwa tarian ini sudah ada sejak dulu kala. Dengan adanya tarian ini masyarakat Lewouran yang hidupnya terpisah-pisah dapat berkumpul dan saling membantu. Hal yan sama juga diungkapkan oleh ibu Lusia Ema Kwuta. Beliau mengatakan bahwa: Dalam tarian ini juga ada 3 gerakan penting yaitu gerakan bajo tehe, gerakan sepi tehe dan gerakan soka sele yang dilakukan sesuai irama alu dan lesung. Nilai yang lainnya yaitu nilai kerjasama dimana masyarakat dulu itu biar hidup terpisah tapi tetap saling membantu. Mereka hanya mendengar suara lesung dan Alu dan teriakan jug jo $e$ mereka dengan sendirinya datang berkumpul dan membantu sesama mereka yang menumbuk padi. Hal ini juga harus ditiru oleh kita sekarang. Nilai budaya lain yang bisa diambil jika dilihat dari gerakan dalam tarian Raja Sine yaitu bagaimana semangat kerjasama nenek moyang kita serta tanggungjawab penari dalam memperagakan bagaimana menghasilkan beras. Tarian ini dibawahkan secara berkelompok dimana di perankan oleh penari laki-laki dan perempuan. 
Gerakan yang dilakukan setiap kelompok penari berbeda-beda sesuai peran mereka masing-masing. Gerak yang dilakukan meceritakan bagaimana kerjasama yg dilakukan mereka untuk menghasilkan beras yang banyak.Ada yang bertugas menumbuk padi, membersikan beras dan ada yang menari untuk menghibur yang lain. (catatan lapangan)

Hasil wawancara diatas menjelaskan bahwa nilai kebersamaan atau kerjasama yang dilakukan oleh nenek moyang mereka dahulu diekspresikan masyarakat Lewouran melalai gerak tari dalam tarian Raja Sine. Nilai kebersamaan (kerjasama) yang sudah ada sejak nenek moyang telah ditanamkan rasa senasip, persaudaran yang merupakan ciri khas yang telah diwariskan dari turun temurun. Nilai kebersamaan dalam tarian Raja Sine perlu ditumbuh kembangkan dalam aspek kehidupan masyarakat sebagai salah satu contoh bagi generasi penerus untuk selalu saling tolong menolong dalam menciptakan keharmonisan hidup bermasyarakat.

\section{d. Nilai Tanggungjawab}

Nilai tanggungjawab merupakan sikap dan perilaku seseorang untuk melaksanakan tugas dan kewajibannya yang seharusnya dia lakukan terhadap diri sendiri, masyarakat, lingkungan (alam sosial dan budaya) negara dan Tuhan Yang Maha Esa. Dalam Draf Grand Design Pendidikan Karakter diungkapkan nilai-nilai yang akan dikembangkan dalam budaya satuan pendidikan formal dan nonformal salah satunya adalah nilai tanggungjawab yaitu melakukan tugas dengan sepenuh hati, bekerja dengan etos kerja yang tinggi, berusaha keras untuk mencapai prestasi terbaik (giving the best), mampu mengontrol diri dan mengatasi stres, berdisiplin diri, akuntabel, terhadap pilihan dan keputusan yang diambil.

Tarian Raja Sine adalah tarian yang dapat dibawahkan oleh semua kalangan dan dalam tarian ini mengandung nilai tanggungjawab yang harus dipertahankan.

Berdasarkan hasil wawancara dengan Bapak Metias Wato Kwuta pada tanggal 30 Mei 2019. Beliau mengatakan bahwa: Dalam tarian ini ada 3 gerakan penting yang dilakukan. Gerakan yang mempragakan bagaimana cara menumbuk padi yaitu gerak bajo tehe, gerak sepi tehe dan gerak soka
sele.Jadi dilihat dari gerakan ini kita bisa mengetahai bagaimana tanggungjawab mereka dalam membawahkan tarian ini.

Hasil wawancara diatas menjelaskan bahwa nilai tanggungjawab yang dilakukan oleh nenek moyang mereka dahulu diekspresikan masyarakat Lewouran melalai gerak tari dalam tarian Raja Sine.Berdasarkan pengamatan yang dilakukan oleh peneliti memang benar nilai tanggungjawab memang ada dalam tarian Raja Sine jika dilihat melalui gerak yang dilakukan oleh masing-masing penari. Sebelum membawakan tarian ini penari diberi kepercayaan memperagakan masing-masing gerakan dalam tarian tersebut.Agar dapat menghasilkan gerakan yang baik penari terus melatih diri sampai menghasilkan gerakan yang indah dipandang.

\section{e. Nilai Disiplin}

Pada prinsipnya tarian Raja Sine merupakan suatu bentuk upacara untuk membangun kebersamaan dan kekompakan dalam pergaulan hidup masyarakat Lewouran. Dalam upacara ini nilai kedisiplinan terwujud dalam kekompakan antara semua suku yang ada di dusun Lewouran.Kedisiplinan terlihat dari gerakan yang dilakukan oleh para penari pada saat membawahkan tarian Raja Sine.Disiplin berarti tindakan yang menunjukan perilaku tertip dan patuh terhadap berbagai ketentuan dan peraturan (Elkabumaini dkk, 2016:46). Sikap dan perilaku yang mencerminkan ketaatan, kepatuhan, ketertipan, kesetiaan, ketelitian, keteraturan perilaku sesorang terhadap norma dan aturan ditunjukan oleh para penari pada saat membawahkan tarian tersebut. Berdasarkan hasil pengamatan peneliti tarian ini dibahwakan secara kelompok.Mereka sangat disiplin dalam melakukan gerakan dan gerakan tersebut harus kompak dan sesuai dengan bunyi ketukan alu dan lesung. Gerakan penari pada saat menumbuk padi dilakukan secara serentak dan tidak ada kesalahan yang dilakukan oleh penari lain pada saat menari mengikuti irama bunyi lesung tersebut. Sebelum membawahkan tarian para penari berkumpul mendengarkan arahan dari pelati agar tidak gerogi dan tetap fokus menari (catatan lapangan).Hal tersebut menunjukan bagaimana kekompakan yang dilakukan oleh 
para penari tersebut.Kekompakan tersebut muncul karena para penari disiplin atau patuh terhadap peraturan yang dibuat mereka pada saat mau membawakan tarian ini.

\section{Relevansi nilai-nilai dalam tarian Raja Sine dengan pendidikan nilai dalam pembelajaran PKn}

Raja Sine adalah salah satu tarian yang memiliki nilai-nilai pendidikan yang dapat dikembangkan dan diterapkan kepada peserta didik melalui pendidikan nilai dalam pembelajaran pendidikan kewarganegaraan. Dalam ranah pendidikan nilai, seorang pendidik tidak hanya efektif dalam kegiatan belajar mengajar dikelas saja (transfer of knowledge) tetapi lebih-lebih dalam relasi pribadinyanya dan "modeling-nya" (transfer of attitude and values) baik kepada peserta didik maupun kepada seluruh anggota komunitas sekolah. Pendidikan nilai adalah pengajaran atau bimbingan kepada siswa agar menyadari nilai kebenaran, kebaikan dan keindahan melalui proses pertimbangan nilai yang tepat dan pembiasaan bertindak yang konsisten. Pendidikan yang benar adalah suatu usaha pembinaan pribadi manusia untuk mencapai tujuan akhirnya (perilaku hubungan dengan Tuhan dan diri sendiri) dan sekaligus untuk kepentingan masyarakat (perilaku hubungan dengan diri sendiri, keluarga masyarakat dan alam semestanya).

Tujuan pendidikan nilai adalah human being sejalan dengan hakikat tujuan pendidikan nilai, yaitu memanusiakan manusia muda Driyarkara (dalam Elmubarok 2009:19).Pendidikan nilai nertujuan membantu peserta didik untuk bertumbuh dan berkembang menjadi pribadi yang lebih bermanusiawi (semakin "penuh" sebagai manusia) berguna dan berpengaruh dalam masyarakatnya, yang bertanggung jawab serta bersifat proaktif dan kooperatif, pribadi yang cerdas, berkealihan tetapi tetap humanis.

Tujuan pendidikan nilai yang lain yaitu membantu peserta didik agar mampu memahami dirinya, sehingga dapat menempatkan dirinya secara integral dalam kehidupan bersama. Melalui pendidikan sosial atau humaniora hal itu dapat dicapai dengan mewariskan nilai-nilai tertentu melalui pendidikan yang dijalankan. Agar tujuan ini dapat tercapai maka diperlukan system pembelajaran dan pendidikan yang humanis serta mengembangkan cara berpikir aktif, positif dan keterampilan yang memadai (income generating skills).

Pendidikan nilai sudah menjadi bagian dari upaya pencapain visi pembangunan nasional, serta sejalan dengan prioritas pendidikan nasional.Hal ini jelas terlihat dalam standar kelulusan (SKL) pada jenjang pendidikan sebagaimana ditetapkan dalam Peraturan Menteri Pendidikan Nasional Nomor 23 Tahun 2006, dimana secara implicit atau sksplisit setiap SKL memuat substansi nilai/karakter. Substansi karakter termuat dalam SKL tersebut kemudian dituangkan dalam grand designpendidikan karakter yang dibuat tanggal 23 Oktober 2010. Dimana untuk semua pencapaian SKL diberikan keterangan tentang karakter apa yang dikembangkan. Untuk jenjang sekolah dasar draf grand design pendidikan karakter tersebut dapat dilihat dalam Tabel 1 berikut:

Tabel 1

Substansi Nilai Karakter dalam SKL SD/MI/SDLB/Paket A

\begin{tabular}{|c|c|c|}
\hline No & Rumusan SKL & Nilai /Karakter \\
\hline 1 & $\begin{array}{l}\text { Menjalankan ajaran agama yang dianut sesuai dengan } \\
\text { tahap perkembangan anak }\end{array}$ & Iman dan takwa, bersyukur \\
\hline 2 & Mengenal kekurangan dan kelebihan diri sendiri & Jujur, mawas diri \\
\hline 3 & $\begin{array}{l}\text { Mematuhi aturan-aturan sosial yang berlaku dalam } \\
\text { lingkungannya }\end{array}$ & Disiplin \\
\hline 4 & $\begin{array}{l}\text { Menghargai keberagaman agama, budaya, suku, ras, dan } \\
\text { golongan social ekonomi dilingkungan sekitarnya }\end{array}$ & $\begin{array}{l}\text { Terbuka, nasionalikstistik, menghargai } \\
\text { (respect), harmonis,toleran }\end{array}$ \\
\hline 5 & $\begin{array}{l}\text { Menggunakan informasi tentang lingkungan sekitar } \\
\text { secara logis, kritis dan kreatif. }\end{array}$ & Bernalar, kreatif, kritis, tanggap \\
\hline 6 & $\begin{array}{l}\text { Menunjukan kemampuan berpikirlogis, kritis dan kreatif } \\
\text { dengan bimbingan guru pendidik. }\end{array}$ & Bernalar, kreatif, kritis \\
\hline 7 & $\begin{array}{l}\text { Menunjukan rasa keinginan yang tinggi dan menyadari } \\
\text { potensinya. }\end{array}$ & $\begin{array}{l}\text { Bernalar, } \\
\text { intelektual) }\end{array}$ \\
\hline
\end{tabular}


8 Menunjukan kemampuan memecahkan masalah Bernalar, mampu memecahkan masalah sederhana dalam kehidupan sehari-hari. (problem solving)

9 Menunjukan kemampuan mengenali gejala alam dan Terbuka, bernalar, kuriositas sosial dilingkungan sekitarnya.

10 Menunjukan kecintaan dan kepedulian terhadap Peduli, tanggungjawab lingkungan

11 Menunjukan kecintaan dan kebanggan terhadap bangsa, Nasinalistik kewargaan (civic) dan negara dan tanah air Indonesia. kewarganegaraan (citizenship)

12 Menunjukan kemampuan untuk melakukan kegiatan seni Nasionalistik dan budaya local

13 Menunjukan kebiasaan hidup bersih, sehat, bugar, aman Bersih, tanggungjawab, menghargai dan memanfaatkan waktu luang. kesehatan, kreatif

14 Berkomunikasi secara jelas dan santun Bersih, tanggung jawab, menghargai kesehatan, kreatif

15 Bekerja sama dalam kelompok, tolong-menolong, dan Gotong-royong, peduli dan menjaga diri sendiri dalam lingkungan keluarga dan teman sebaya

16 Menunjukan kegemaran membaca dan menulis Gigih, tekun

17 Menunjukan keterampilan menyimak,berbicara, Bernalar, teliti membaca, menulis dan berhitung.

Samani dan Haryanto 2012:26-28 (dalam Dole, 2015)

Dalam pembelajaran yang ada di sekolahsekolah dasar terlalu banyak nilai karakter yang dapat diajarkan pendidik kepada peserta didik. Maka dari itu , pendidik harus bisa pilahkan mana yang harus diutamakan dan yang harus diajarkan pada peserta didik. Berikut ini kementrian pendidik nasional menjelaskan empat nilai karakter utama yang menjadi beban pendidik untuk menyampaikan kepada peserta didik yaitu kejujuran, ketangguhan, kepedulian dan kecerdasan. Berikut dijelaskan nilai-nilai dari tarian Raja Sine yang relevan dengan pendidikan nilai dengan pembelajaran PKn SD/MI yaitu sbb:

Tabel 2

Relevansi nilai-nilai dalam Tarian Raja Sine dengan Kompetensi Inti dan Kompetensi Dasar pembelajaran PKn SD/MI

\begin{tabular}{|c|c|c|c|c|}
\hline No & Rumusan SKL & Nilai/ karakter & $\begin{array}{c}\mathrm{KI} / \mathrm{KD} \text { yang relevan } \\
\text { dalam Pembelajaran PKn }\end{array}$ & $\begin{array}{l}\text { Nilai dalam } \\
\text { tarian Raja } \\
\text { Sine }\end{array}$ \\
\hline 1 & $\begin{array}{l}\text { Mematuhi aturan-aturan sosial yang } \\
\text { berlaku dalam lingkungannya }\end{array}$ & Disiplin & $\begin{array}{l}\text { Kelas I KI } 2 \text { KD } 2.2 \text {, } \\
\text { kelas II KI } 2 \text { KD } 2.2 \text { dan } \\
\text { kelas III KI } 2 \text { KD } 2.2\end{array}$ & $\begin{array}{l}\text { Nilai Disiplin } \\
\text { Nilai Estetika, }\end{array}$ \\
\hline 2 & $\begin{array}{l}\text { Menghargai keberagaman agama, } \\
\text { budaya, suku, ras, dan golongan } \\
\text { social ekonomi dilingkungan } \\
\text { sekitarnya }\end{array}$ & $\begin{array}{l}\text { Terbuka, } \\
\text { nasionalistik, } \\
\text { menghargai } \\
\text { (respect), harmonis, } \\
\text { toleran }\end{array}$ & Kelas II KI.2,KD2.1 & $\begin{array}{l}\text { Nilai } \\
\text { solidaritas }\end{array}$ \\
\hline 3 & $\begin{array}{l}\text { Menunjukan kebiasaan hidup } \\
\text { bersih, sehat, bugar, aman dan } \\
\text { memanfaatkan waktu luang. }\end{array}$ & $\begin{array}{l}\text { Bersih, } \\
\text { tanggungjawab, } \\
\text { menghargai } \\
\text { kesehatan, kreatif }\end{array}$ & $\begin{array}{l}\text { Kelas I KI } 2 \text { KD } 2.1 \text {, } \\
\text { Kelas } 11 \text { KI } 1 \text { KD } 2\end{array}$ & $\begin{array}{l}\text { Nilai } \\
\text { tanggung } \\
\text { jawab. }\end{array}$ \\
\hline 4 & $\begin{array}{l}\text { Bekerja sama dalam kelompok, } \\
\text { tolong-menolong, dan dan menjaga } \\
\text { diri sendiri dalam lingkungan } \\
\text { keluarga dan teman sebaya }\end{array}$ & $\begin{array}{l}\text { Gotong royong, } \\
\text { peduli }\end{array}$ & $\begin{array}{l}\text { Kelas } 1 \text { KI } 2 \text { KD2.3 dan } \\
\text { kelas III KI } 2 \text { KD2.3 }\end{array}$ & $\begin{array}{l}\text { Nilai } \\
\text { kebersamaan } \\
\text { (kerjasama), } \\
\text { nilai } \\
\text { solidaritas }\end{array}$ \\
\hline
\end{tabular}

Berdasarkan tabel diatas dapat disimpulkan bahwa nilai-nilai budaya dari tarian Raja Sine relevan dengan pendidikan nilai dalam pembelajaran PKn yaitu Nilai estetika yaitu pada kelas I KI 2 KD2.2, kelas II KI 2 KD2.2 dan kelas III KI 2 KD2.2. Nilai solidaritas 
yaitu pada kelas II KI2KD2.1. Nilai kebersamaan (kerjasama) yaitu pada kelas $1 \mathrm{KI}$ 2 KD2.3 dan kelas III KI 2 KD2.3. Nilai tanggungjawab yaitu pada kelas I KI 2 KD2.1, kelas 11 KI 1 KD2.1. Nilai disiplin yaitu padapada kelas I KI 2 KD2.2, kelas II KI 2 KD2.2 dan kelas III KI 2 KD2.2.

\section{SIMPULAN DAN SARAN}

Raja Sine adalah tarian adat yang dimiliki oleh masyarakat Lewouran yang sudah ada sejak zaman nenek moyang mereka. Tarian yang menceritakan bagaimana proses menumbuk padi sampai menghasilkan beras. Tarian Raja Sine ini biasa dibawahkan pada saat acara-acara penting seperti penerimaan tamu sebagai acara hiburan dan bisa dibawahkan oleh semua kalangan.

Nilai-nilai budaya dari tarian Raja Sine relevan dengan pembelajaran PKN di SD yaitu nilai estetika pada kelas I KI $2 \mathrm{KD} 2.2$, kelas II KI 2 KD2.2 dan kelas III KI 2 KD2.2 Nilai solidaritas yaitu pada kelas II KI2 KD2.1. Nilai kebersamaan (kerjasama) yaitu pada kelas $1 \mathrm{KI} 2 \mathrm{KD} 2.3$ dan kelas III KI 2 KD2.3. Nilai tanggungjawab yaitu pada kelas I KI 2 KD2.1, kelas 11 KI 1 KD2.1. Nilai disiplin yaitu padapada kelas I KI 2 KD2.2, kelas II KI 2 KD2.2 dan kelas III KI 2 KD2.2

\section{DAFTAR PUSTAKA}

Daeng Hans. 2004. Antropologi Budaya. Flores-NTT. Penerbit: Nusa Indah

Dagur, Antony Bagur.2008. Budaya Daerah Dalam Konteks

Komunikasi.Ende:Arnoldus

Dole, Frumensius. 2015. Tesis. Kesulitan Guru SD di Kecamatan Detukeli Kabupaten Ende dalam Mengembangkan Pembelajaran IPS Berorientasi Pendidikan Karakter, Berbasis Kearifan Lokal.Tesis. Malang: Universitas Negeri Malang

Elkabumaini, Nasin dan Ruhyana.2016. Panduan Implementasi Pendidikan Budi Pekerti. Bandung:Yrama Widya

Elmubarok, Zaim. 2009. Membumikan Pendidikan Nilai. Bandung: Alfabeta
Koentjaraningrat (2005). Pengantar Antropologi II. Jakarta : PT. Rineka Cipta

Iskandar. 2013. Metodologi Penelitian Pendidikan Dan Sosial. Jakarta: Referensi

Jurahman, Yohanes B. 2014. Pengantar Ilmu Sosial dan Budaya Sosial. Salatiga:Widya Sari Press

Samani, Muchlas. 2012. Konsep dan Model Pendidikan Karakter. Bandung: PT. Remaja Rosdakarya

Solihatin, $\mathrm{Hj}$ Etin. 2013. Strategi Pembelajaran PPKN. Jakarta: PT. Bumi Aksara

Sugiyono (2010). Metode Penelitian Pendidikan. Bandung : Alfabeta

Tilaar, H.A.R. 2000. Pendidikan Kebudayaan Dan Masyarakat Madani Indonesia. Bandung: Remaja Rosdakarya

Uran, Fabianus Boli. 2018. Di Balik Kesunyian Lewouran Duli Detun Saka Ruka Paji Wuri. Maumere: Carol

Zakiyah,Qiqi Yuliati Dan H. A. Rusdiana.2014.Pendidikan Nilai.Bandung: Pustaka Setia

http://sofyan. Blogspot.Com/2009/05/ implementasi-pendidikan-nilai-dalampendidikan. Akses hari/tanggal: Sabtu, 02 Maret 2019 jam 10.28 Am 